\title{
Tari Manyakok, Tari Turun Mandi, dan Tari Podang Perisai sebagai Ekspresi Budaya Masyarakat Melayu Riau
}

\author{
Irdawati \\ Institut Seni Indonesia (ISI) Padangpanjang \\ Jalan Bahder Johan Padangpanjang Sumatera Barat
}

\begin{abstract}
This paper is describing the research about the value of culture of Malayan people through three different dance in Kuantan Singingi Regency of Riau Province. These dance are Manyakok Dance, Turun mandi Dance, and Podang Perisai Dance. From these results, the conclusion is these form of dance are growing and spread, based on their own culture. Manyakok Dance reflect the tradition of fishing, and have the symbol that related with the culture which consists of seven type of motions. Turun mandi Dance is a ritual dance that related with the birth of a child. Turun mandi Dance has five type of motions. Podang Perisai Dance is a symbol of patriotizm in defending the region from the attack of enemy. Tari Podang Perisai has four type of motions.
\end{abstract}

Keywords: Dance Mangoyak,Dance Turun mandi, Dance Podang Parisai, Malay Culture

\begin{abstract}
ABSTRAK
Tulisan ini merupakan hasil penelitian tentang nilai-nilai budaya masyarakat Melayu melalui tiga tari tradisional di Kabupaten Kuantan Singingi Provinsi Riau. Tiga bentuk tari tradisional tersebut adalah Tari Manyakok, Tari Turun mandi, dan Tari Podang Perisai. Ketiga tari tradisional hidup dan berkembang dilatarbelakangi oleh budaya masyarakat setempat. Tari Manyakok merupakan cerminan budaya menangkap ikan yang memiliki simbol-simbol berkaitan dengan budaya masyarakatnya yang terdiri atas tujuh ragam gerak. Tari Turun mandi merupakan tarian ritual yang berhubungan dengan kelahiran seorang anak. Tari Turun mandi memiliki lima ragam gerak. Tari Podang Perisai merupakan simbol kepahlawanan dalam mempertahankan daerah dari serangan musuh. Tari Podang Perisai memiliki empat ragam gerak.
\end{abstract}

Kata kunci: Tari Manyakok, Tari Turun mandi, Tari Podang Parisai, Budaya Melayu 


\section{PENDAHULUAN}

Kuantan Singingi merupakan sebuah kabupaten yang masyarakatnya berbudaya Melayu. Penduduknya terdiri atas: Melayu, Minangkabau, Batak, Jawa, dan sebagian Cina. Meskipun terdiri atas berbagai suku dan budaya, namun dalam kehidupan sehari-hari ada satu kesepakatan tidak tertulis, bahwa mereka diatur oleh satu payung adat Melayu. Penduduk Kuantan Singingi sebagian besar terdiri atas suku Melayu setempat. Suku-suku yang berasal dari daerah Indonesia lainnya memperlihatkan kecenderungan yang kuat dan hampir menyamai suku Melayu yang ada. Suku Minangkabau dan Jawa merupakan dua suku yang sangat dominan sebagai kaum pendatang, kemudian keturunan Cina dalam jumlah yang sangat terbatas berpengaruh di sektor perekonomian ( Hamidy, 2000: 20).

Struktur masyarakat adat Kuantan Singingi didasarkan pada "pemegang teraju" (pemegang kendali pimpinan) yang dikenal dengan lapisan masyarakat paling atas yaitu sembilan orang datuk dengan wilayah teritorial masing-masing disebut urang godang (orang besar). Dalam konteks adat disebut "pucuk bulat dan urat tunggal dalam luhak". Pembagian wilayah tertera dalam ungkapan adat tanah lah babingka, luhak lah bekabung, rantau beraja (wilayah kekuasaan telah dibentuk, wilayah kekuasaan sudah dibagi-bagi atas beberapa negeri, tiap negeri mempunyai seorang pemimpin). Kekhasan pakaian Melayu adalah teluk belanga warna kuning, bersarung kain songket Melayu, kopiah (peci) berpita hitam kain beludru, memakai pending emas, dan keris pusaka (Hamidy, 2000: 25).

Perkembangan zaman memberikan pengaruh terhadap kehidupan dan kelangsungan seni tradisi pada masyarakat Melayu. Kelahiran Tari Manyakok, Tari Turun mandi dan Tari Podang Perisai merupakan tari tradisi konstruksi realitas budaya Melayu Kuantan Singingi. Ketiga tari tersebut sebagai representasi dan ekspresi budaya masyarakat pendukungnya.

\section{METODE}

Sifat seni pertunjukan yang tidak statis, dikarenakan masyarakat yang pendukungnya yang selalu berubah-ubah (Umar Kayam, 2000: 21), dalam pencarian informasi tidak terikat dalam satu bentuk model metode yang baku dan ketat seperti dalam ilmu pasti. Ia disesuaikan dengan kebutuhan penelitian, yang terkadang dapat berkembang kepada informasi lain yang tak terpikirkan sebelumnya. Bila memperhatikan keterangan tersebut maka jelaslah bahwa penelitian ini tergolong pada jenis penelitian kualitatif. Hal tersebut tergambar dari pandangan Alasuurtari yang menyebutkan bahwa salah satu sifat dari data kualitatif adalah merupakan data yang memiliki kandungan yang kaya, multi-dimensional, dan kompleks (Soedarsono, 2001 : 3-15).

Teknik pengumpulan data yang digunakan adalah studi pustaka, wawancara, dan pengambilan gambar lewat kamera video dan pemotretan guna membantu proses mengenal tari itu sendiri serta pembuatan laporan. Setelah data terkumpul langkah berikutnya adalah upaya pengelompokan atau penyeleksian data sesuai dengan permasalahan yang hendak dijawab. Proses berikutnya adalah mendeskripsikan, menganalisis, dan menginterpretasi data agar tidak terjadi kontraversi antara satu dengan yang lainnya. Data yang dirasa belum terpenuhi maka akan dilakukan penelitian ulang.

\section{HASIL DAN PEMBAHASAN}

Di Kuantan Singingi terdapat tiga tari sebagai kristalisasi dari pola kehidupan masyarakatnya. Tari Manyakok, Tari Turun mandi, dan Tari Podang Perisai merupakan konstruksi realitas sebagai penggambaran 
budaya masyarakat setempat. Tari Manyakok adalah salah satu bentuk tari tradisional yang eksis sampai saat ini sebagai sarana hiburan. Kehadiran Tari Manyakok dilatarbelakangi oleh kondisi alam yang kehidupan masyarakatnya menangkap ikan. Tari Turun mandi dilatarbelakangi oleh suatu kepercayaan bahwa setiap anak yang baru lahir harus melalui suatu upacara yang disebut Turun mandi untuk keselamatannya. Tari Podang Perisai merupakan realisasi untuk mempertahankan wilayah teritorial dari serangan musuh yang ingin menguasai kampung halaman, sehingga tari ini memuat nilai-nilai kepahlawanan para leluhur. Filosofi kehidupan masyarakat Melayu Kuantan Singingi tercermin dalam tiga tari yang mensimbolkan falsafah alam terkembang jadi guru, realisasinya terlihat pada simbol gerak yang diekspresikan penari pada tiga tari tersebut.

Fenomena tersebut memiliki maksud mempersatukan atau menggabungkan suatu segi pengalaman manusia yang sudah dikenal, baik dengan yang mengatasi pengalaman maupun pengungkapannya. Simbol dapat berupa sebuah kata, tindakan, ataupun gambaran. Dengan kata lain, simbol menghubungkan usaha pencairan manusia dengan realitas yang lebih besar, bahkan yang lebih tertinggi (Dilistone, 2002: 28). Pada prinsipnya simbol yang terdapat dalam gerak tari adalah merupakan simbol, tindakan, dan gambaran dari segala aspek

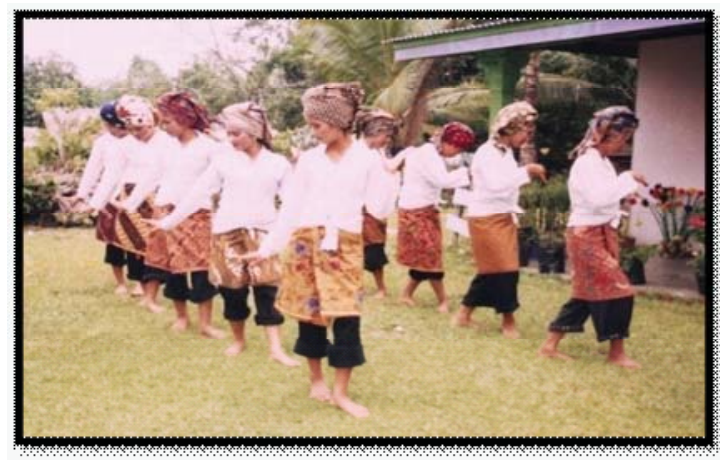

Gambar 1

Gerak Poi Basamo (Foto: Repro Irdawati, 2014) aktivitas yang terkait dengan masyarakat adat Melayu Kuantan Singingi. Hal tersebut dapat diamati dan dicermati berdasarkan nama ragam gerak yang terdapat dalam tari tradisi tersebut.

\section{Tari Manyakok}

Tari Manyakok adalah tari tradisi yang dilatarbelakangi oleh kondisi alam yang terdapat di wilayah Pangean yaitu salah satu daerah di Kuantan Singingi. Letak Pangean berdekatan dengan sungai, dan sering dilanda banjir. Pada musim banjir daerah ini tidak produktif untuk berladang. Dengan kondisi tersebut, masyarakat memanfaatkannya untuk menangkap ikan yang berasal dari luapan sungai. Ketika air sudah mulai surut menangkap ikanpun dilakukan dengan mengunakan sakok (alat penangkap ikan mirip jaring). Aktivitas menangkap ikan tersebut disebut dengan manyakok.

Kegiatan yang terkait dengan manyakok biasanya dilakukan sekali dalam satu tahun, yakni pada bulan September hingga Maret (Badan Statistik Kuantan Singingi, 2004: 1). Pada waktu banjir kegiatan manyakok belum dapat dilaksanakan, tetapi setelah air surut barulah secara bersama-sama masyarakat setempat melaksanakan kegiatan ini.

Kegiatan manyakok diwujudkan menjadi sebuah tarian yang dikonstruksikan sebagaimana aktivitas menangkap ikan seperti manyakok. Properti yang digunakan adalah sakok. Keindahan gerak terletak pada ekspresi penari dalam melahirkan gerakan yang

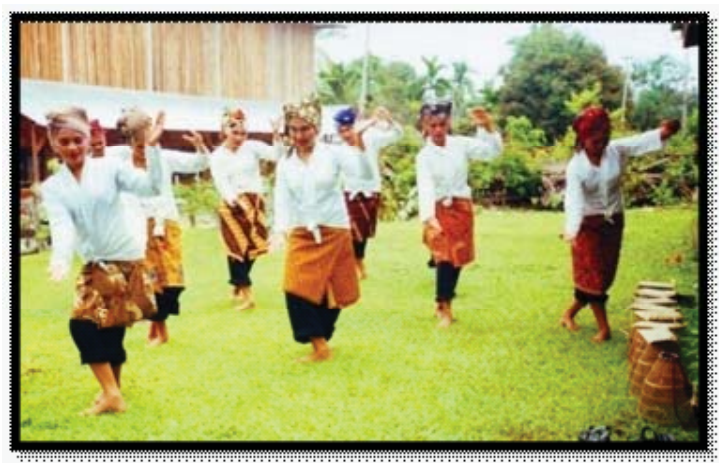

Gambar 2

Gerak Manobang (Foto: Repro Irdawati, 2014) 


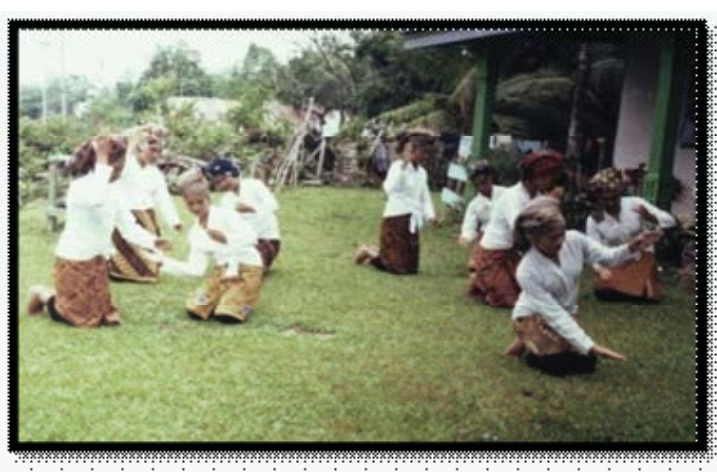

Gambar 3

Gerak Potong dan Gerak Bolah

(Foto: Repro Irdawati, 2014)

dipolakan sesuai dengan nilai-nilai budaya manyakok. Pada Gambar 1 (satu) sampai dengan 7 (tujuh) dapat dilihat ragam gerak, kostum, dan properti Tari Manyakok.

Poi Basamo mengadung unsur kebersamaan. Poi berarti pergi, basamo adalah bersama. Gerak pai basamo memperlihatkan bahwa azas kebersamaan menjadi satu ciri yang mendasar bagi masyarakat. Makna simbolis kebersamaan pun mereka aplikasikan dalam gerak Tari Manyakok, yaitu pada gerak Poi Basamo.

Manobang adalah sebuah kegiatan yang terkait dengan kebutuhan properti tari yaitu sakok. Manobang dibangun dari kata tobang yang berarti tebang, yang diberi awalan me. Dengan demikian Manobang mengandung arti menebang pohon. Pohon yang mereka tebang adalah pohon bambu sebagai bahan dasar pembuatan sakok (alat penangkap ikan seperti terlihat di sebelah kanan penari).

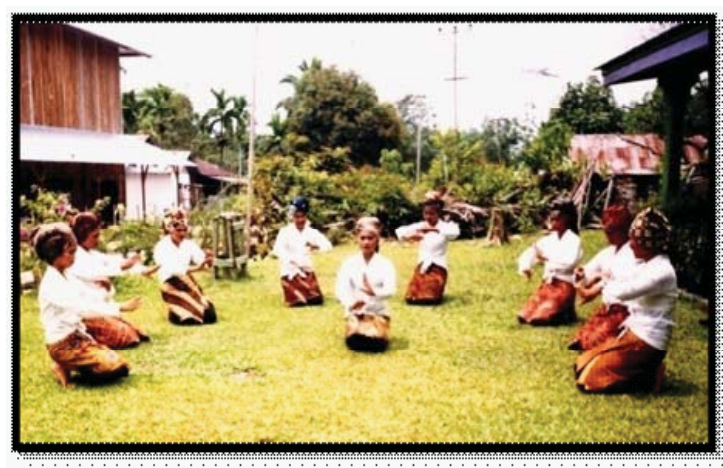

Gambar 5

Gerak Manjalin (Foto: Repro Irdawati, 2014)

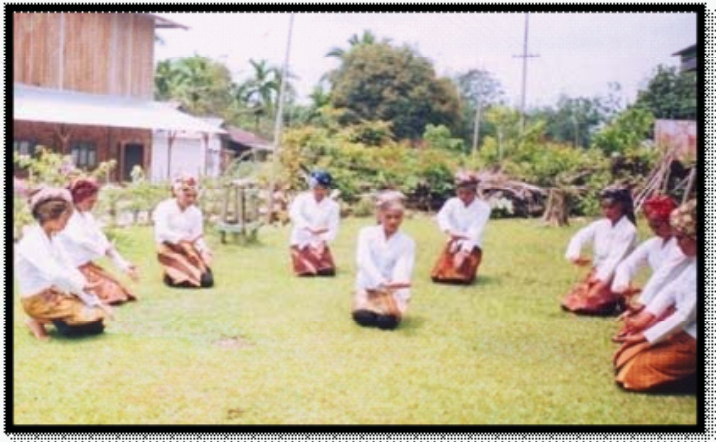

Gambar 4

Gerak Marawik (Foto: Repro Irdawati 2014)

Gerak gambar 3 merupakan proses pembuatan sakok. Potong sama artinya dengan potong dalam bahasa Indonesia, sedangkan Bolah berarti belah. Potong yang dimaksud dalam simbol gerak ini adalah proses memotong bambu sesuai dengan ukuran panjang sakok yang dibutuhkan. Bambu yang telah dipotong-potong kemudian proses membelah bambu tersebut dalam ukuran lebih kurang $1 \mathrm{~cm}$. Simbol gerak potong dan Bolah juga mengandung makna kehati-hatian .

Marawik identik dengan kata meraut. Hal yang diraut adalah bambu-bambu yang telah dipotong dan dibelah tersebut. Bambu ukuran $1 \mathrm{~cm}$ diraut lebih kurang menjadi sebesar lidi dan harus halus serta merata.

Manjalin artinya menjalin (Manjalin) bilah-bilah bambu yang telah diraut. Menjalin di sini bermakna usaha membuat sakok yang biasanya diikat dengan rotan yang telah diraut pula menjadi tali. Akhirnya, setelah proses ini selesai barulah sakok dapat di-

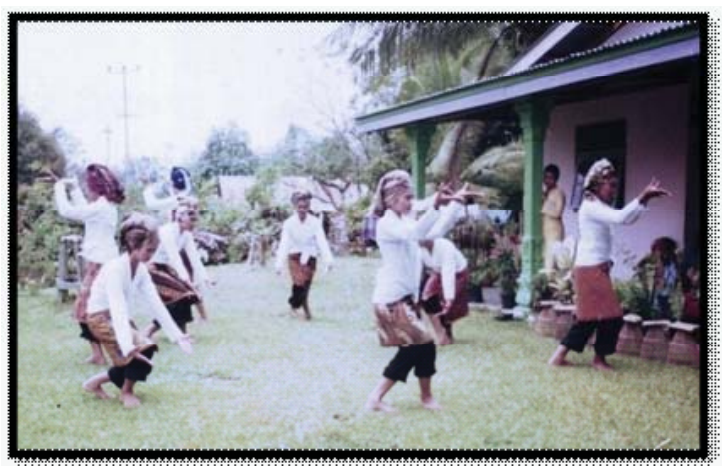

Gambar 6

Gerak Buang Sarok (Foto: Repro Irdawati, 2014) 


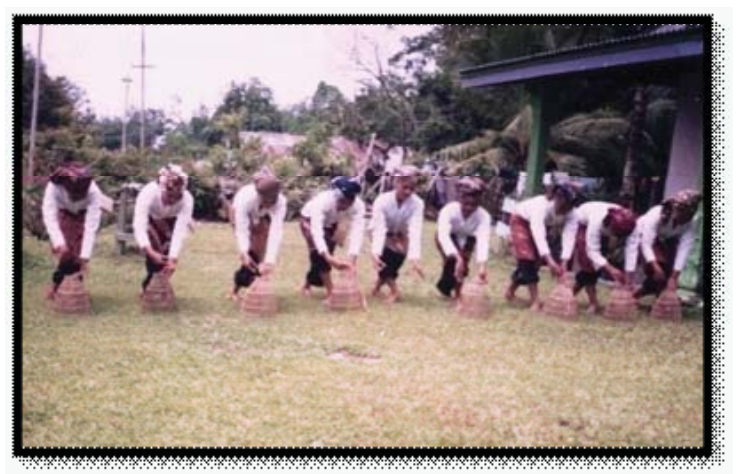

Gambar 7

Gerak Manyakok (Foto: Repro Irdawati, 2014)

fungsikan sebagai penangkap ikan. Gerakan dapat dilihat pada Gambar 6.

Buang Sarok berarti buang sampah. Sampah yang mereka maksud adalah rantingranting yang terdapat pada bambu setelah disisir mereka anggap sebagai sampah. Artinya sampah dibuang agar tidak mengotori tempat mereka. Proses pembuangan sampah diaplikasikan melalui stilisasi gerak ke dalam Tari Manyakok.

Gambar 7 memperlihatkan simbol gerak manyakok. Proses penggunanan properti sakok dalam menangkap ikan. Gerakan menangkap ikan ini secara umum dilakukan dengan cara bersama oleh penduduk, sehingga gerakan merupakan realisasi menangkap ikan. Tarian manyakok ditarikan oleh gadis-gadis remaja dengan menggunakan pakaian tradisi sebagaimana kegiatan menangkap ikan di sungai.

2. Tari Turun mandi sebagai Tari Ritual

Keberadaan seni pertunjukan dalam berbagai upacara amat tergantung pada sifat dan jenis upacara. Seni pertunjukan merupakan bagian integral yang saling mendukung bagaikan dua sisi mata uang. Kehadiran seni pertunjukan tidak hanya sebagai pelengkap semata akan tetapi sudah menjadi satu kesatuan. Di masyarakat tertentu ditemukan antara upacara dengan seni pertunjukan bagaikan sebuah dialektika. Tidak ada upacara tanpa seni pertunjukan dan sebaliknya (Hadi, 2000: 29-30).
Di Kuantan Singingi, adat masyarakat Melayu merupakan satu proses yang dilalui dari lahir sampai dewasa. Anak yang baru lahir membutuhkan doa dari kedua orang tua dan masyarakat setempat. Anak diarak ke sungai yang pelaksanaannya disebut dengan turun mandi. Dalam pelaksanaannya disediakan berupa: Tunam, kunyit, jariangau, boneka, bintang, bintang limau, payung, kain panjang, dua buah kelapa, satu ekor ayam, puntung, dan Sisampek.

Tunam adalah sepotong kain yang ditata sedemikian rupa hingga mirip dengan tali pusar seorang bayi yang sudah lepas dari tubuhnya. Tunam ini menyimbolkan bahwa syarat pertama atau sebuah tanda sang anak sudah selayaknya untuk dilakukan upacara turun mandi. Kunyit dan jariangau merupakan persyaratan kelengkapan dalam pembacaan mantra untuk mengusir makhluk halus yang akan mengganggu sang anak dalam kehidupannya kelak. Boneka dijadikan sebagai simbol anak yang akan turun mandi. Bintang adalah sebuah wadah untuk membawa sesaji yang akan dilaksanakan dalam acara turun mandi, bintang limau adalah wadah yang berisikan khusus untuk limau yang akan digunakan dalam ritual turun mandi. Payung berfungsi sebagai pelindung bagi anak. Kain panjang difungsikan sebagai alat penggendong anak. Kelapa disimbolkan sebagai harapan agar sang anak bermanfaat bagi orang banyak nantinya setelah dewasa. Ayam dilambangkan sebagai suatu harapan agar sang anak nantinya mampu memberi dan melindungi garis keturunannya di masa mendatang. Puntung diibaratkan sebagai sampah yang tak berguna, yang artinya menyimbolkan jika ada sifat yang tercela atau tidak terpuji bagi sang anak akan dibuang saat ritual berlangsung. Sisampek sejenis kelengkapan lain yang digunakan dalam acara turun mandi dan melambangkan kemeriahan upacara.

Penari pada tari Turun mandi adalah wanita. Peran penari wanita mengiringi 
dukun yang berada di depan untuk melaksanakan prosesi. Dukun membaca mantramantra terhadap sesajian yang telah disediakan yang bertujuan untuk melindungi seluruh personil termasuk penari agar tidak terganggu oleh roh-roh jahat atau penunggu sungai. Dukun mengambil posisi sebagai penggendong anak dengan kain panjang dan memegang Tunam dalam barisan tari. Sambil membaca mantra dukun menyemburkan kunyit dan jariangau ke depan, samping kiri, dan kanan yang bertujuan untuk mengusir roh-roh jahat yang ingin mengganggu pelaksanaan ritual dan pergelaran tari. Dukun kemudian mengelilingi seluruh pentas tempat pertunjukan diadakan.

Pengakuan masyarakat Melayu ditemukan empat argumen dasar yang memposisikan dukun sebagai satu profesi $\mathrm{Cu}^{-}$ kup dipandang oleh masyarakatnya, yaitu: pertama, dukun memiliki sesuatu kekuatan gaib yang diberikan Tuhan. Kedua, dukun membaca ayat-ayat Alqur'an di awal sebagai pembukaan pembacaan mantra kemudian di akhir kegiatan juga menggunakan kalimat-kalimat Allah. Ketiga kekuatan bathin sang dukun pun diucapkan pada ramuan, dan keempat dalam ramuan yang dipilih juga memiliki kekuatan (Hamidy, 1986: 90).

Manusia, roh-roh, arwah para leluhur, dan wujud tertinggi (penguasa alam semesta) selalu dipikirkan dalam satu keterikatan yang sangat erat (Fernandez, 1990: 107-108). Konsep pikiran Fernandez ini juga terjadi dalam kehidupan masyarakat Kuantan Si-ngingi. Salah satu realitasnya terlihat dari upacara turun mandi. Proses upacara ritual turun mandi penari sama sekali tidak melakukan gerak tari, jadi mereka sematamata hanya melaksanakan prosesi saja. Dahulu ritual turun mandi dilaksanakan langsung di sungai Batang Kuantan. Namun saat ini dilakukan di halaman rumah atau dibuatkan pentas pertunjukannya. Tari turun mandi mempunyai lima ragam gerak sebagai berikut.

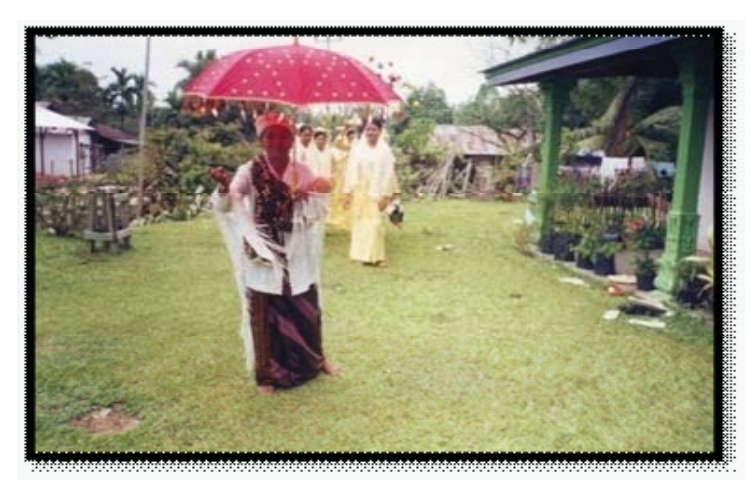

Gambar 8

Gerak Somba (Foto: Repro Irdawati, 2014)

\section{a. Gerak Somba}

Tari Turun mandi sebagai tarian simbolisasi ritual adat dimulai dengan pembukaan. Pembukaan dapat saja berupa vokal dan dapat pula dilakukan dengan gerakan. Dalam Tari Turun mandi dukun yang bertindak sebagai pelaku melaksanakan gerak Somba (gerak sembah). Secara harafiah mengandung makna meminta izin kepada penonton.

\section{b. Gerak Babintang}

Pertunjukan telah dibuka dan dikuasai oleh dukun, sehingga rombongan penari masuk berbaris sebanyak dua baris memasuki tempat pertunjukan untuk menari. Penari yang berperan menjunjung bintang $l i$ mau yang berisikan sesaji yang sudah disiapkan menjelang pertunjukan berlangsung. Sepuluh orang penari bertugas membawa sesaji, berupa: ayam, punting, kelapa, dan Sisampek.

Gerakan tari diambil dari rangkaian sesaji yang dijunjung oleh penari yang menyerupai bintang. Simbol tersebut mewakili sifat bintang yang selalu terang benderang dan tak pernah pudar. Pemaknaannya agar sang bayi untuk masa depan dengan harapan secerah bintang di langit. Simbol bintang yang digunakan bermakna perumpamaan sifat suatu benda. Bentuk gerak Babintang yang dimaksud dapat dilihat gambar

\section{c. Gerak Bacungak}

Bacungak adalah satu simbol dalam kegiatan menghias diri. Aktivitas tari ini tergam- 


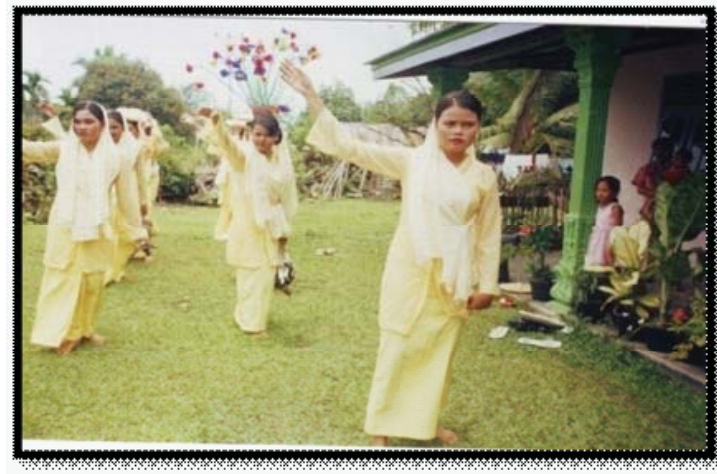

Gambar 9

Gerak Babintang(Foto: Repro Irdawati, 2014)

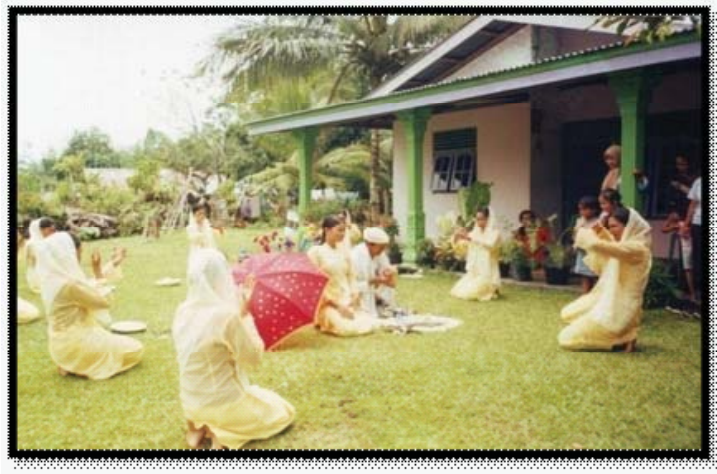

Gambar 10

Gerak Bacungak (Foto: Repro Irdawati, 2014)

bar melalui properti yang telah disediakan dalam Sisampek. Pada gerak Bacungak merupakan peniruan/imitasi gerak sang dukun yang ditiru oleh penari. Pada awal gerak $B a$ cungak seluruh penari dalam posisi duduk mengelilingi penari dukun. Salah satu anggota penari bertindak sebagai ibu dari yang punya hajat. Posisi melingkar dilakukan penari, dukun bergerak mengambil sesaji yang ada dalam bintang limau yang dibawa oleh penari lainnya. Isian bintang limau yang diambil berupa: sepiring rebusan limau purut, sepiring minyak goreng, sepiring kue, ketupat, sisir, bedak, dan cermin kecil.

Rebusan limau purut dioleskan ke rambut boneka dan wajahnya dengan simbolisasi pensucian bayi dari kotoran. Minyak goreng disimbolkan sebagai pelancar rezeki. Sepiring kue merupakan kue yang akan diberikan kepada penari. Simbol sepiring kue ini bermakna agar anak nantinya tidak lupa diri akan nilai-nilai ajaran agama bahwa di dalam rezeki setiap orang masih terdapat rezeki orang lain. Ketupat adalah makanan yang diberikan kepada bayi. Beragamnya pesan dalam gerak Bacungak, yakni 'proses pembelajaran' agar anak nanti setelah dewasa memiliki sifat-sifat terpuji baik di lingkungan keluarga maupun dalam bermasyarakat.

\section{d. Gerak Robuik Sisampek}

Robuik dalam dialek daerah berarti rebut. Jika digabung dengan kata Sisampek bermakna satu kegiatan berebut Sisampek.

Simbol gerak Sisampek mengemban pesan social. Penari yang bertindak sebagai orang tua (ibu) agar mendidik anaknya menjadi seorang yang darmawan. Inilah makna yang diemban dalam simbol Sisampek ini. Pesan moral ditujukan juga kepada seluruh audiens yang hadir menyaksikan pergelaran. Pesan pertunjukan agar penonton merasakan hal yang sama apabila mereka tidak hanya sekedar mencari nilai hiburan.

\section{e. Gerak Mairiang}

Mairiang merupakan bahasa daerah setempat yang identik dengan mengiring dalam bahasa Indonesia. Gerak tersebut merupakan satu pertanda bahwa proses tari ritual telah selesai dipergelarkan yang menggambarkan perasaan bahagia sambil membawa rangkaian bunga berbentuk bintang yang diambil dari wadah bintang limau.

Musik iringan tari menggunakan calempong Onam dan gendang kecil. Calempong Onam adalah ensambel musik yang terdiri atas calempong berjumlah enam buah. Calempong ini adalah sejenis gong yang berukuran kecil dalam tingkatan nada yang berbeda yang menghasilkan bunyi bila dipukul.

\section{Tari Podang Perisai}

Tari Podang Perisai memiliki makna mempertahankan wilayah dengan cara perang menggunakan pedang. Tari ini dianggap sakral, sehingga disediakan seperangkat sesaji berupa kembang dan limau (jeruk tipis). Di awal pertunjukan diawali ritual dengan 


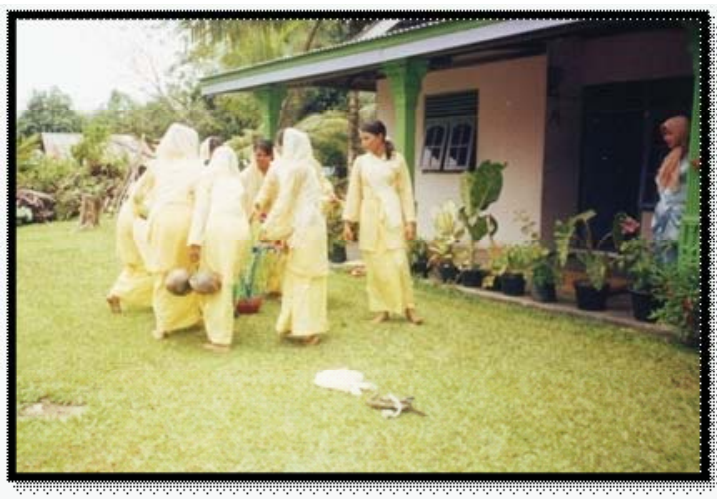

Gambar 11

Gerak Robuik Sisampek (Foto: Repro Irdawati, 2014)

menghadirkan dukun untuk membacakan mantra sambil meracik limau ke dalam baskom yang sudah di isi air dan kembang. Di dalam pertunjukan penari bertindak sebagai dukun (orang yang paham betul dengan seni bela diri) dan sekaligus sebagai penari. Kemudian setelah limau diracik calon murid diminta balimau (mandi dengan racikan). Proses penyiraman air dimulai dari kepala sampai membahasi sekujur badan. Adapun tujuan dari ritual ini adalah agar sang murid menguasai materi pembelajaran dengan cepat (Wawancara Doli di Pangean, 25 Juni 2013).

Doli juga menyatakan bahwa penari $P_{0}-$ dang Perisai setiap akan menari selalu melalui proses maracik limau. Di sini tujuannya adalah memberikan kekebalan terhadap penari agar tidak mengalami kecelakaan atau tergores oleh pedang yang digunakan sebagai properti. lima simbol gerak dalam Tari Podang Perisai, yakni gerak Rantak dua balah, gerak sosor, gerak Paliang, gerak Kuak ilalang, gerak lantiang Pauah.

\section{Gerak Rantak Duo Balah}

Rantak dalam bahasa daerah berarti rentak, sedangkan duo bolah adalah dua belah. Gerakan dilakukan oleh penari yang berpe-ran sebagai pahlawan putera daerah sebagai pembela kampung

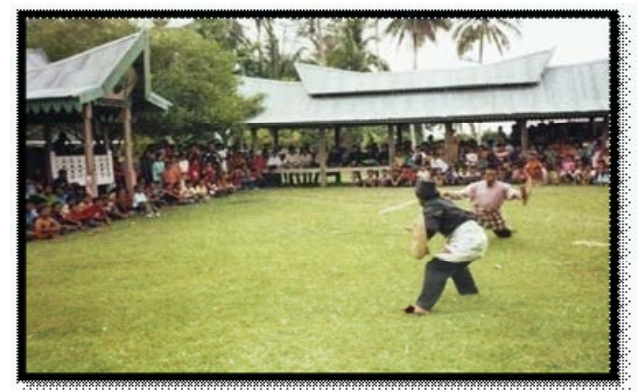

Gambar 13 Gerak Rantak Duo bolah (Foto: Repro Irdawati, 2014)

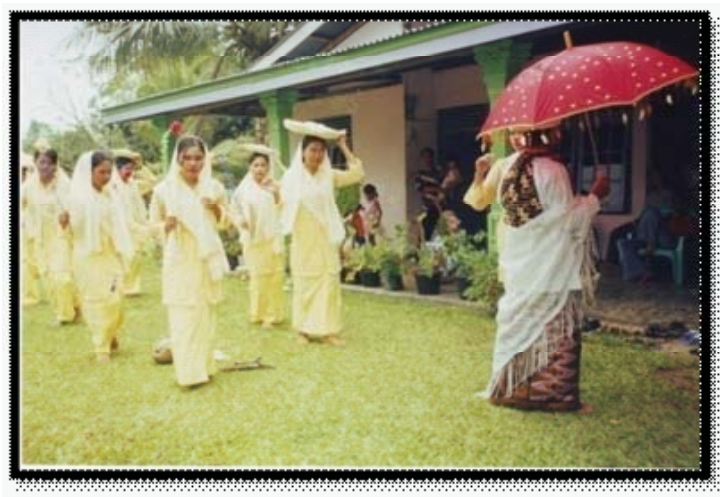

Gambar 12

Gerak Mairiang (Foto: Repro Indriwati, 2014)

halaman. Aspek bunyi pada getaran tanah yang diakibatkan hentakan kaki menjadi ciri gerakan. Bunyi yang menggema dan tanah yang bergetar memperlihatkan keampuhan dan keperkasaan pemuda-pemuda daerah Pangean.

\section{a. Gerak Sosor}

Gerak sosor yaitu sebagai salah satu nama gerak dalam silat tradisi yang identik dengan menyusun suatu rancangan strategi untuk menyerang dan pertahanan diri terhadap musuh yang sudah di hadapan mata.

b. Gerak Paliang

Paliang mengandung makna berpaling yang artinya menghindar. Gerak-gerak $P a$ liang adalah satu usaha yang dilakukan penari untuk berpaling atau menghindar serangan musuh berupa menghadapkan tubuh ke arah kiri atau kanan agar tidak tertusuk pedang lawan. Jadi pengambilan nama gerak ini berasal dari unsur bahasa setempat yang mengandung makna menghindar dari serangan musuh.

\section{c. Gerak Kuak Ilalang}

Kuak sama dengan arti Kuak dalam bahasa Indonesia, sedangkan ilalang juga sama artinya dengan Hilalang. Gerak Kuak ilalang merupakan sebuah gerak yang diambil dari aktivitas sehari-hari masyarakat petani mencari sesuatu yang tersembu- 


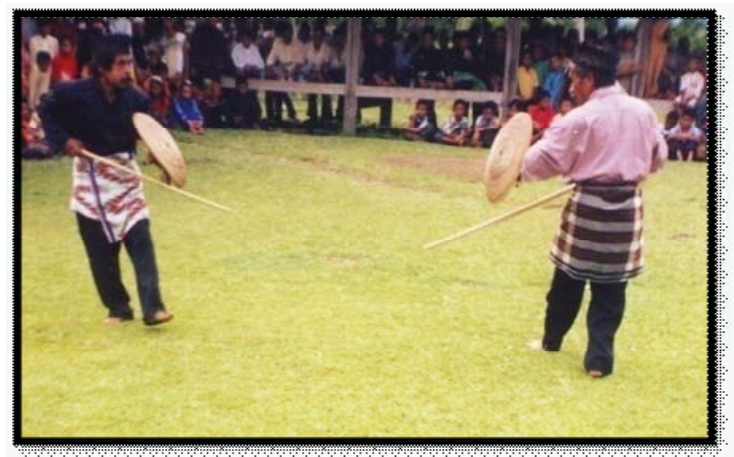

Gambar 14

Gerak Sosor (Foto: Repro Irdawati, 2014)

nyi di permukaan tanah atau satu usaha menguak hilalang agar seseorang dapat melewati daerah yang banyak ditumbuhi ilalang tersebut. Konteks gerak ini terlihat aktivitas menguak hilalang yang terkait dengan mencari sesuatu yang ada di tanah. Pengaplikasiannya terhadap gerak merupakan salah satu cara mendorong serangan lawan yang hendak membunuh, seperti gambar berikut.

\section{d. Gerak Lantiang Pauah}

Gerak lantiang Pauah cerminan aktivitas masyarakat sehari-hari yang ingin memetik buah-buahan. Lantiang adalah suatu usaha melempar batu atau sepotong kayu yang ditujukan ke satu arah. Pauah adalah sejenis buah yang hampir sama bentuknya dengan mangga. Proses melempar buah pauh ini dijadikan sebagai nama gerak dan diyakini sebagai salah satu cara untuk melumpuhkan lawan. Gambar 17 berikut adalah merupakan gerakan lantiang Pauah.

Pertunjukan Tari Podang Perisai terlihat para penari melakukan gerak dengan im-

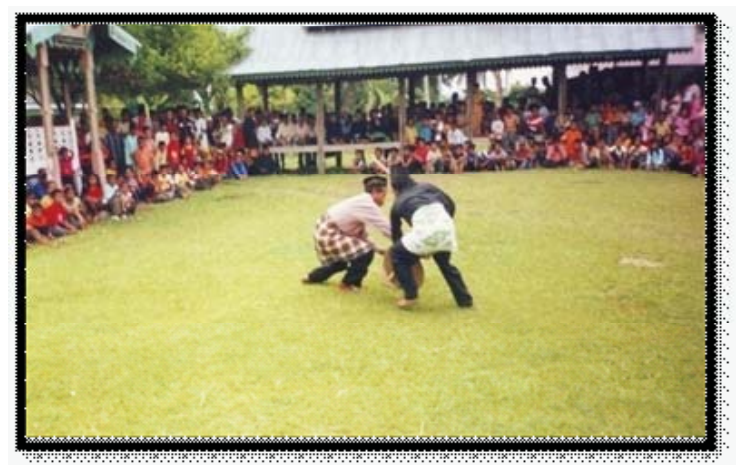

Gambar 16

Gerak Kuak Ilalang (Foto: Repro Irdawati, 2014)

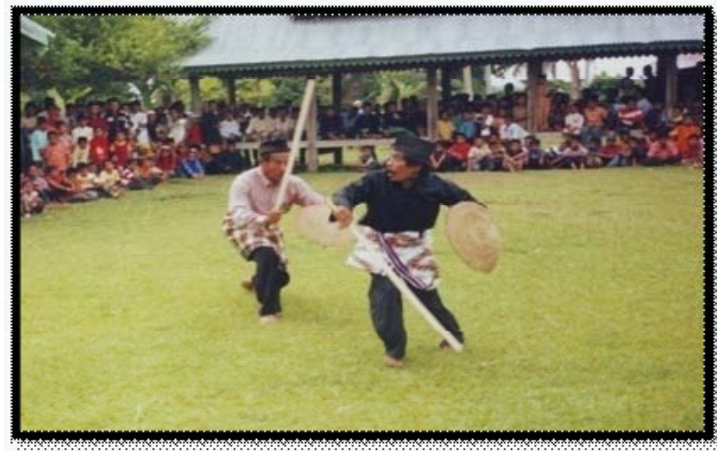

Gambar 15

Gerak Paliang (Foto: Repro Irdawati, 2014)

provisasi yang sudah terpola. Jadi, apabila tari ini ditarikan di waktu yang berbeda maka akan terlihat terjadinya sedikit perubahan garis gerak yang dilalui. Dengan demikian, terbuka kemungkinan apabila dua orang penari benar-benar piawai terhadap seni bela diri, maka semakin kaya pula pengembangan-pengembangan gerak yang akan mereka lakukan.

\section{SIMPULAN}

Tiga tari yakni Tari Manyakok, Tari Turun mandi, dan Tari Podang Perisai sebagai ekspresi budaya masyarakat Melayu di Kuantan Singingi mencerminkan simbol-simbol gerak yang berangkat dari proses pembuatan sakok yang berfungsi untuk menangkap ikan di sungai. Tari Turun mandi dan Tari Podang Perisai mencerminkan kepercayaan keberkahan dengan menghadirkan dukun dalam pertunjukan.

Maracik limau mencerminkan tingkat kecerdasan murid dalam mempelajari ge-

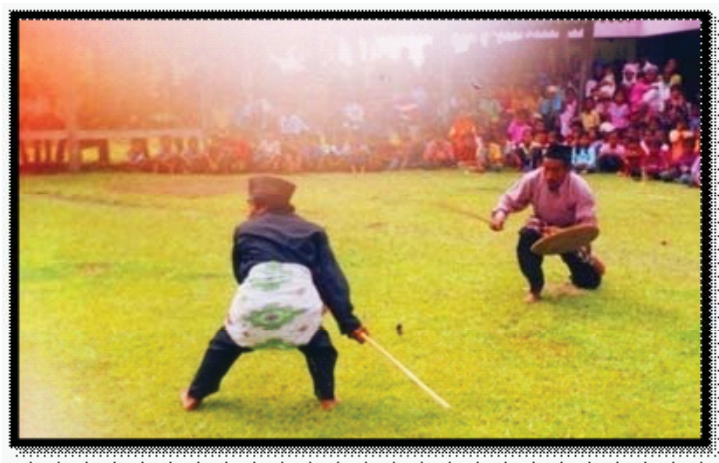

Gambar 17

Gerak Lantiang Pauah (Foto: Repro Irdawati, 2014) 
rak-gerak yang dalam Tari Podang Perisai. Kembang yang digunakan dalam Tari turun mandi, seperti kembang mawar meninggalkan aroma harum di air yang dimandikan anak didik. Hal ini merupakan satu strategi dan sugesti dalam mengakali seorang calon anak didik agar lebih serius mempelajari tarit. Masyarakat adat Melayu Kuantan Singingi mengakui filosofi kehidupan mereka dari alam takambang jadi guru.

Ragam gerak dari ketiga tari adalah sebagai berikut. Tari Manyakok terdiri atas gerak Poi Basamo, Manombang, Potong, Bolah, Merawik, Menjalin, Buang Sarok dan Manyakok. Gerak Tari Turun mandi adalah gerak Somba, Babintang, Bacungak, Robuik Sisampek, dan Mairiang. Gerakan pada Tari Podang Parisai, yakni: Rantak Dua Bolah, Sosor, Paliang, Kuak Ilalang, dan Lantiang Pauah.

\section{Daftar Pustaka}

Badan Pusat Statistik

2003 Pangean dalam Angka. Kuantan Singingi: BPS.

Dillistone, F.W.

2002 The Power of Symbols. Terj. A. Widyamartaya. Yogyakarta: Kanisius
Fernandez, SVD, Stephanus Ozias

1990 Citra Manusia Budaya Timur dan Barat. Yogyakarta: Nusa Indah

R.M. Soedarsono

2001 Metodologi Penelitian Seni Pertunjukan dan Seni Rupa. Bandung : MSPI.

Sumandiyo Hadi

2000 Seni dan Ritual Agama. Yogyakarta: Yayasan Untuk Indonesia.

Umar Kayam

2000 "Seni Pertunjukan Kita", dalam Jurnal MSPI X.

U.U. Hamidy

2000 Masyarakat Adat Kuantan Singingi. Pekan Baru: UIR Press.

1986 “Dukun Melayu Rantau Kuantan Riau". Pekan Baru: Proyek Penelitian dan Pengkajian Kebudayaan Melayu (Melayulogi) Departemen Pendidikan dan Kebudayaan RI.

1982 Sikap Orang Melayu Terhadap Tradisinya di Riau. Pekan Baru: Bumi Pustaka 